\title{
Research and development of artificial intelligence system for waste identification
}

\author{
Kirill Epifantsev ${ }^{1}$ and Olga Kozlova ${ }^{1}$ \\ ${ }^{1}$ St. Petersburg State University of Aerospace Instrumentation, Russian Federation, Bolshaya morskaya \\ str., Saint-Petersburg, 19000, Russia
}

\begin{abstract}
The article discusses the possibilities of using an artificial intelligence system for waste recognition. In article is collection some interesting program product software for waste management. The author emphasizes the possibility of developing a series of software products for waste management and developing waste management competencies in St. Petersburg residents. In the last task, the ECO-365 software product may also be useful for better ecology in all peace. Subsequently, the development of another software product was carried out, which allowed using artificial intelligence to determine the size of waste. The emphasis in this study is made on software products used not only for recognizing plastic, but on the most dangerous from the point of view of ecology, LED lamps, batteries, incl. lithium telephone batteries and batteries. Of course, the creation of fandomats of this kind, an increase in their number should provoke a widespread growth of the environmental movement, the popularization of projects for the separate collection of waste.

\section{Keywords}

ECO-365 software product, development of theory of intellectual, artificial intelligence, waste identification waste separation
\end{abstract}

\section{Introduction}

Modern waste separation systems are becoming increasingly expensive to implement with artificial intelligence systems built into expensive types of cameras with advanced optical capabilities. The article considers the possibility of using the created program that operates from a camera with a low expansion and allows identifying several groups of waste glass containers and plastic bottles. According to GOST 30772-2001 " Resource Saving. Waste treatment. Terms and definitions" [1], consumer waste includes "residues of substances, materials, items, products, goods that have partially or completely lost their original consumer properties". It also notes that this category of waste should include not only MSW generated in households, "but also waste generated in offices, commercial enterprises, small industrial facilities, schools, hospitals, and other municipal institutions." This definition corresponds to the foreign term "municipal solid waste". The legal basis for the classification of solid waste in Russia is the Federal classification catalog of waste (FKKO), which classifies waste by origin, aggregate state and hazard, using the term "municipal solid waste" [2]. Classification of hazardous waste is based on the order of the Ministry of health of the Russian Federation No. 511 "on approval of criteria for classifying hazardous waste as a hazard to the environment". Government Decree No. 712 of August 16, 2013 introduced the concept of certification of waste of hazard class I-IV: "For waste of hazard classes I-IV included in the Federal classification catalog of waste, individual entrepreneurs and legal entities draw up and approve a passport in the form approved by decree of the Government of the Russian Federation No. 712 of August 16, 2013. A copy of the passport certified by individual

III International Workshop on Modeling, Information Processing and Computing (MIP: Computing-2021), May 28, 2021, Krasnoyarsk, Russia

EMAIL: epifancew@gmail.com (K. Epifantsev)

ORCID: 0000-0002-5705-0282 (K. Epifantsev)

(c) (i) (C) 2021 Copyright for this paper by its authors.

Use permitted under Creative Commons License Attribution 4.0 International (CC BY 4.0)

CEUR Workshop Proceedings (CEUR-WS.org) 
entrepreneurs and legal entities, as well as copies of documents confirming that the type of waste is classified as a specific hazard class, are sent to the territorial body of the Federal service for supervision of natural resources at the place of economic activity by individual entrepreneurs and legal entities in a way that allows them to determine the fact and date of their receipt, or are handed over to them under a signature." Introduced changes to the existing system of household waste removal caused an increase in tariffs for services $[3,4]$.

\section{Materials and Methods}

As one of the methods of generalization and analysis of information, the method of combining and comparing information on the development of garbage sorting machines by Russian manufacturers was used Currently, the most popular information resource on waste recycling is the channel in the Telegram messenger "Zero Waste". This channel is conducted by the state Corporation "Rostec" and is dedicated to a number of problems related to waste recycling and the creation of modern waste recycling systems. It is important to emphasize the popularization of fandomat in Russia, thanks to the RT-Invest project, which includes a whole waste-processing class. In particular, a number of fandomats developed by RTInvest are the result of collecting more than $2000 \mathrm{~kg}$ of clean recyclable materials collected in Kazan schools, thanks to a network of such established fandomats. However, not only this company is a manufacturer of fandomats. Let's look at the main companies that are involved in this process - the data is presented in the Table 1.

\section{Table 1}

Russian Fandomat Manufacturers

\begin{tabular}{|c|c|c|}
\hline Name of company & Foto & Specifications \\
\hline $\begin{array}{l}\text { https://r- } \\
\text { stanok.ru/fandomat/ }\end{array}$ & 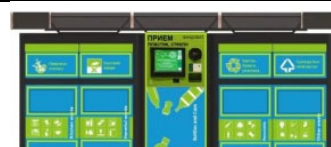 & $\begin{array}{l}\text { Reception of plastic and glass bottles, } \\
\text { large enough; } \\
\text { Comfortable tank for waste storage. }\end{array}$ \\
\hline $\begin{array}{l}\text { https://www.vsekioski.ru/c } \\
\text { atalog/fandomat/ }\end{array}$ & & $\begin{array}{l}\text { Touch screen; } \\
\text { Coupon Printer; } \\
\text { Tare recognition system; } \\
\text { Protection from vandals. }\end{array}$ \\
\hline https://greenat.ru/at-s1 & [? & $\begin{array}{l}\text { Magnetic Card Reader; } \\
\text { Pressing receiving device; } \\
\text { Modem Barcode Scanner; } \\
\text { Storage capacity: 5-15 cubic meters; } \\
\text { Capacity: up to } 20 \text { units / min Power: } 10 \\
\text { kW; } \\
\text { Accepted packaging: } 0.33-5 \text { liters; } \\
\text { Body material: Sandwich panel. }\end{array}$ \\
\hline https://taras.group/ & & $\begin{array}{l}\text { Acceptance of aluminum and plastic } \\
\text { containers; } \\
\text { No advertising monitor; } \\
\text { No crease. }\end{array}$ \\
\hline
\end{tabular}


http://www.rtinvest.com/news/304/

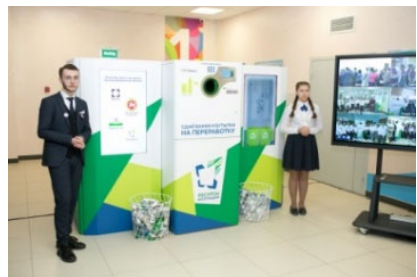

The presented device has a Barcode

Scanner;

Storage capacity: 5-15 cubic meters;

Capacity: up to 20 units / min;

Power: $10 \mathrm{~kW}$;

Accepted packaging: 0.33-5 I;.

Body material: Sandwich panel

To manage the system of waste removal and disposal, 4 programs were allocated, working as a fullfledged ERP-system:

1. «RG-soft: waste Removal» - program designed for the analysis and monitoring of waste removal companies, analysis of the threshold of garbage limits, section accounting for waste disposal, As well as: accounting of recyclable materials, Accounting of own coupons, accounting of third-party coupons, Environmental reporting, formation of documents, Accounting of payments from customers. As a drawback-the lack of environmental monitoring of the waste disposal area [3$5]$.

2. «RG-soft: waste Treatment and disposal»- offers possible forms of waste treatment, but in the absence of the proposed methods at the landfill, as appropriate, which occurs in most cases, does not offer options to sell waste to interested enterprises from other regions. In this case, of course, the carrier has no alternatives other than a simplified waste disposal procedure.

3. «Recycle Map» - with the possibility of pop-up tips on the location of containers for disposal of batteries and incandescent lamps according to the user's geodata [3-5].

4. «1S: Enterprise 8. Waste and recycling management» - the configuration supports the main operational processes in the processing plants, such as the reception and shipment of solid waste (MSW) and recyclables, sorting, processing, transportation and disposal of waste. Integration with various equipment used in such enterprises (scales, cameras, access control systems, etc.) is envisaged [6].

5. «2GIS» - the program and the application allows the search module to determine the location of the organization receiving the waste closest to the location of the interested person.

Of course, the main priorities of the Soft program are: dispatching; calculation salaries drivers; regulatory accounting of fuel. Accounting for the location of the bunkers; a record of the reception of solid waste and recyclables; accounting of weight and volume characteristics of solid waste and recyclable materials; setting circuits receiving and passing solid waste and recyclables; Accounting for certification and quality control of received and shipped MSW and recyclables; Management of electronic queue at the cash Desk receiving and recyclables; etc. [7,8].

It is possible to conclude that the majority of IT applications are concentrated in the field of construction, engineering, mining industry and economy $[9,10]$.

6. Another important product - «ECOScan» on the free software market is a program that has a neural network and is able to recognize various materials and give comments on the possibility of their disposal. This is an Ecoscan software product that was developed by Dutch programmer Rick Buiten and can be downloaded from the App Store.

\subsection{Experimental part}

Currently, in the European Union, ATMs are in $90 \%$ of the stores of such giant chains as Auchan, Kaufland and Aldi. An example of such a recycling terminal is shown in Figure 1:. Development of a product line of terminals for pre-automatic sorting of solid household waste for retail chains, shopping and entertainment centers and transport infrastructure facilities with the possibility of stimulating sales of new ones goods and services is the main topic of the study 


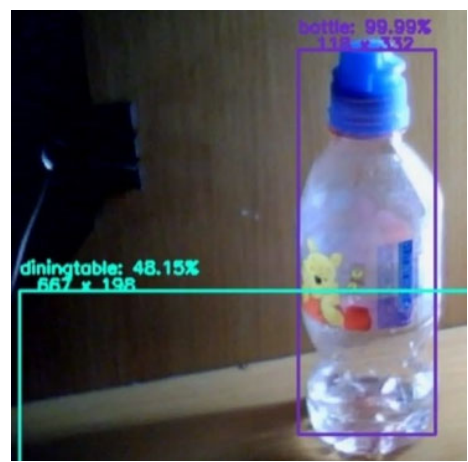

Figure 1: An example of how the program works when identifying the size of a bottle and determining the object

The final product is a system of automatic recognition of images, shapes, geometric parameters and material for further sorting of materials by a specific feature, or for selecting defects from several ideal products passing through the conveyor. Next, it is planned to develop and improve the terminal-machine based on the determination of systematic and instrumental error, modeling the instrument part of the machine in the LabVIEW software module, developing the interface, developing the opticalinstrumental and kinematic system. At the next stage, it is planned to test the installation at enterprises, calibrate the installation, compare it with analogues, and obtain the output results of metrological examination.

To solve this problem, it is planned to use a software product written in Python. This software product can also be used directly at the waste processing plant, and in particular-in the process of teaching schoolchildren and students about waste processing, improving the existing processing technology, creating terminals for receiving waste and automatic sorting. The developed program-a neural network (Figure 2:) - is an application for measuring the size of an object from a direct video stream at a certain distance. The neural network has the possibility of additional self-learning.

In order for the program to work correctly, you need to make settings before you start working

- the focal length of the camera used;

- height (vertical size) of the matrix of the used camera;

- distance to the objects to be measured minimum detection threshold.

If the probability of detecting an object is not high enough, then this object will not be displayed.

When objects are detected in the video, the program draws a frame around them, as well as the name of the class of this object, according to the neural network, the dimensions in millimeters.

After opening the program window, the main function of the program starts. The pre-trained model is loaded into the neural network (from the program catalog), and the camera starts working. Then each frame is extracted from the video and processed. The frame is transformed into a blob object, which is passed through the neural network. If objects are found in the image, and they pass the specified minimum threshold, then their coordinates and name are extracted. This is how we find the dimensions of objects in pixels.

Then, using physical formulas from optics, known data, and camera parameters, we can find the actual dimensions of the thing. It remains to mark it with a frame, sign the class, the percentage of recognition, dimensions (width by height in millimeters)

A software product is currently being developed that focuses on the documentation base for waste classification and has several built-in extended technical reference books, as this product makes up for the shortcomings of previous software products. This product is called ECO 365. During repeated upgrades, the product is updated and now has several versions.

ECO-365 program-assistant in the field of storage, processing and sale of waste for the operator. The program systematized electronic information resources in the field of waste processing, developed in Java script direct code, adapted to the current requirements of Rosprirodnadzor (Russian ecology department). The method of waste search is maximally adapted in the software interface and visually ergonomic for users. As a writing application software was used Java Script language, which is an object-oriented language. Prototyping used in the language causes differences in working with objects in comparison with traditional class-oriented languages. 
The main fields of the program, which are automatically filled in when specifying any type of waste:

- FCCO code-11 digit classifier code;

- Production - what type of industry waste is generated;

- $\quad$ The process - what the process produces waste;

- Name of components, content, \% wt. - composition of waste;

- Physical state and the physical form - the form in which the waste is transported $[11,12]$.

In the process of developing the program, it was necessary to build a promising structure for the development of the project to enter state support (Figure 2:).

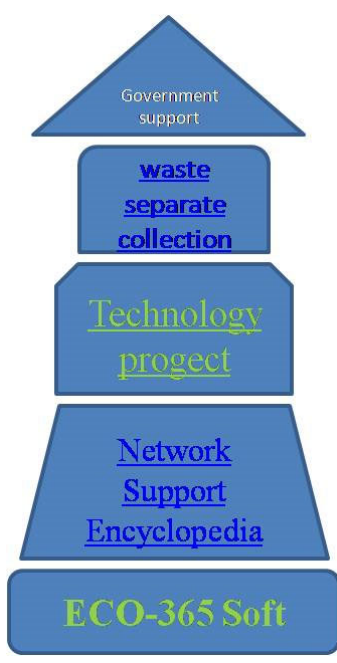

Figure 2: Project development

The program in the form of an application is easily installed on the Windows XP platform and runs provided that the folder is a waste database in Excel format.

The database of Rosprirodnadzor, on which the "engine" of the program is based, is the most extensive and is presented in the form of spreadsheets on several sheets.

Beginning and ending program text in Java Script is presented below.

The main requirements for the creation of the program were - the possibility of free installation on a personal computer, the ability to use the system how professional autodirectory [7-8].

Consider the interface of the program below. Schematically, the work of a software product developed in the university's laboratory and patented in the program system for electronic computers can be seen in the diagram below (Figure 3:).

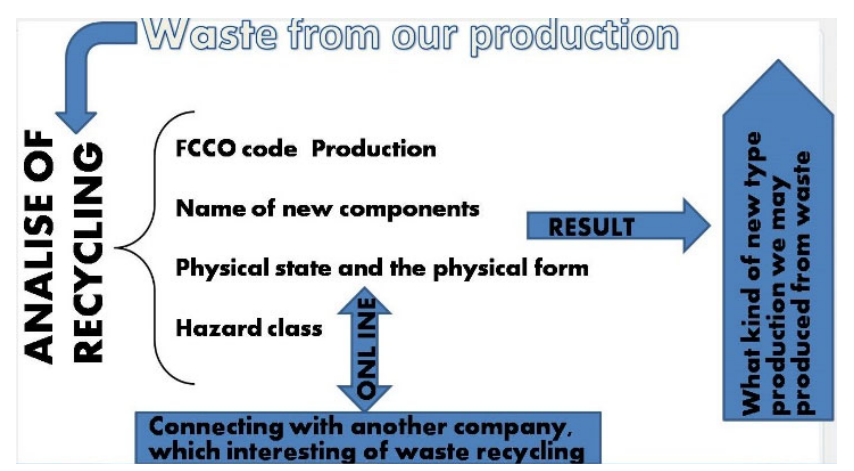

Figure 3: Flow-synthesis algorithm of ECO-365

Below are the versions of software products that have been adapted to meet modern user requirements

The program is easily installed as an application on the Windows XP platform and runs if the folder contains a database in Excel format ("new data"). 
The method of waste search is maximally adapted in the software interface and visually ergonomic for users [5-6]. The scientific and technical novelty of the software product under study is the use of software automation systems and management creation in the waste management system, followed by the possibility of modeling the waste processing cycle and the possibility of implementing waste through the personal accounts of users connected to the network.

Later we research one of very actually problem. At present, it is very important to provide services to the population using robotic automatic terminals (Figure 4:). The terminal, developed by the authors of the article, has an interactive screen and 2 receiving boxes for recycling batteries and used LED lamps. The terminal is equipped with a system for intelligent recognition of objects placed with the subsequent possibility of issuing receipts for the waste placed in it for their sale when purchasing products at a discount in hypermarkets.

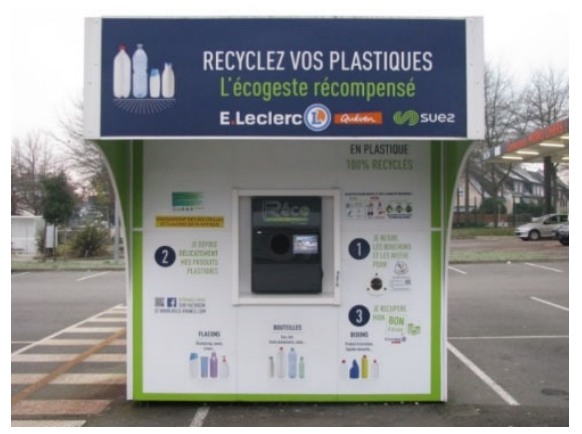

Figure 4: Robotic automatic terminals for plastic waste

Development of a product line of terminals for preliminary automatic sorting of solid household waste for retail chains, shopping and entertainment centers and transport infrastructure facilities with the ability to stimulate sales of new Figure 1: - Example of a waste terminal in France goods and services is the main topic of research. The final product is a system for automatic recognition of patterns, shapes, geometrical parameters and material for further sorting materials according to a specific feature or separating defects from several ideal products passing along the conveyor.

The developed program - a neural network (Figure 5:) - is an application for measuring the size of an object from a direct video stream at a certain distance. The neural network has the possibility of additional self-learning.

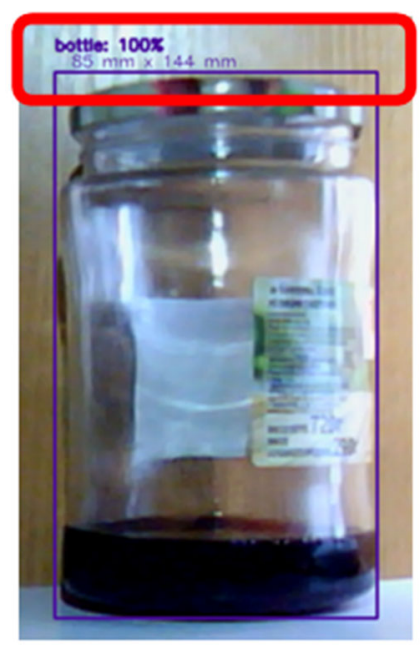

Figure 5: Screenshot of programm for indification of plastic and glass waste. Information about size and main parameters in red frame

For the program to work correctly, you need to make settings before starting work: 
- focal length of the used camera height (vertical size) of the matrix used by the camera distance to objects to be measured;

- minimum detection threshold. If the confidence of object detection is not high enough, then this object will not be displayed.

When objects are detected on the video, the program draws a frame around them, as well as the name of the class of this object according to the neural network and its dimensions in millimeters. Consider the programmatic part of the program code written in Python.

\subsubsection{Results and discussion}

The program module created on the basis of University laboratories ECO-365 it has been patented and is currently being tested.

Currently to admit that this module is only the 1st step in which you want to include and means of geolocation, messaging, opportunity management and creation of the personal account of each user in the environment, with the ability to share videos. It is also expected to broaden the base of the waste, as currently in the standard is not given a detailed description of possible recycling of each waste individually, are not defined a particular company or polygons for mechanical recycling, which havr in the narrow direction of the recycling of a certain list of materials [13].

Undoubtedly, the increase in the family of such programs contributes to the growth of the government's interest in the problems of separate collection and the creation of similar environmental projects. It is important to note that many of the compared programs given at the beginning of the article united the $\mathrm{C}++$ language, but the presented development uses the Java language as one of the most tested from the point of view of interaction with similar programs and further implementation and unloading through similar programs (related in language).

The terminal layout is shown in Figure 6. However, at this stage of its development, a number of tasks arise that are extremely necessary to solve, in particular, to work out the anti-vandal protection system of the terminal, it is necessary to test the receiving and feeding mechanism [14-15].

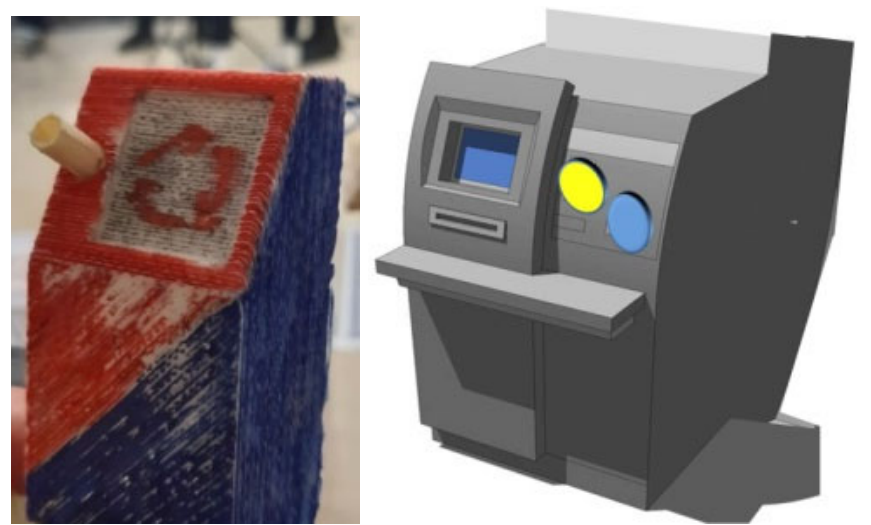

Figure 6: Model of a terminal for collecting batteries and lamps, printed on a 3D printer

The program module created on the basis of University laboratories ECO-365 it has been patented and is currently being tested. 
Table 2

Result of testing waste parameters

\begin{tabular}{|c|c|c|c|c|}
\hline Types of waste & $\begin{array}{l}\text { plastic bottle on a } \\
\text { uniform background }\end{array}$ & $\begin{array}{l}\text { plastic bottle } \\
\text { half on black } \\
\text { background }\end{array}$ & $\begin{array}{l}\text { Glass jar } \\
\text { cleaned }\end{array}$ & $\begin{array}{l}\text { Glass jar with } \\
\text { contamination }\end{array}$ \\
\hline $\begin{array}{c}\text { Foto of } \\
\text { programm }\end{array}$ & & 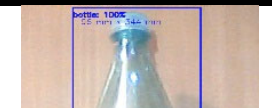 & 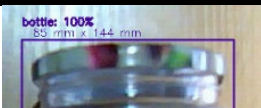 & 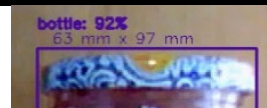 \\
\hline $\begin{array}{c}\text { Nominal Size, } \\
\mathrm{mm}\end{array}$ & $\begin{array}{l}\text { width }-94 \mathrm{~mm} \text {, } \\
\text { height- } 340 \mathrm{~mm}\end{array}$ & $\begin{array}{c}\text { width - } 94 \text { mm, } \\
\text { height - } 340 \\
\mathrm{~mm}\end{array}$ & $\begin{array}{l}\text { width } 87 \mathrm{~mm} \text {, } \\
\text { height } 145 \mathrm{~mm}\end{array}$ & $\begin{array}{l}\text { width - } 64 \mathrm{~mm} \text {, } \\
\text { height - } 96 \mathrm{~mm}\end{array}$ \\
\hline $\begin{array}{c}\text { Size from } \\
\text { program, } \mathrm{mm}\end{array}$ & $\begin{array}{l}\text { width - } 97 \mathrm{~mm} \text {, } \\
\text { height - } 337 \mathrm{~mm}\end{array}$ & $\begin{array}{c}\text { width }-96 \mathrm{~mm} \text {, } \\
\text { height }-344 \\
\mathrm{~mm}\end{array}$ & $\begin{array}{c}\text { width }-96 \mathrm{~mm} \text {, } \\
\text { height }-144 \\
\mathrm{~mm}\end{array}$ & $\begin{array}{l}\text { width }-63 \mathrm{~mm} \text {, } \\
\text { height }-97 \mathrm{~mm}\end{array}$ \\
\hline $\begin{array}{c}\sigma \text { error rate } \\
\text { (width and } \\
\text { heigth), \% }\end{array}$ & $3.2 \% ; 0,9 \%$ & $2.1 \% ; 0,9 \%$ & $2.4 \% ; 0.7 \%$ & $1.6 \% ; 1 \%$ \\
\hline Notes & $\begin{array}{l}\text { The error is due to } \\
\text { poor shooting } \\
\text { quality. So, the } \\
\text { dimensions were } \\
\text { disturbed due to the } \\
\text { camera tilt, the flash } \\
\text { was accepted by the } \\
\text { network as part of } \\
\text { the bottle }\end{array}$ & $\begin{array}{l}\text { The background } \\
\text { reduced the } \\
\text { inaccuracy, but } \\
\text { the network } \\
\text { incorrectly } \\
\text { determined the } \\
\text { height of the } \\
\text { bottle. }\end{array}$ & $\begin{array}{l}\text { Error in width } \\
\text { due to lighting, } \\
\text { the shadow is } \\
\text { taken as an } \\
\text { object. Height } \\
\text { error due to } \\
\text { camera } \\
\text { resolution. }\end{array}$ & $\begin{array}{l}\text { Error in width } \\
\text { due to the } \\
\text { complex shape, } \\
\text { dimensions } \\
\text { were measured } \\
\text { diagonally. The } \\
\text { error in height is } \\
\text { due to the } \\
\text { blurring of the } \\
\text { top on the } \\
\text { background. }\end{array}$ \\
\hline
\end{tabular}

After analyse Table 2 we conclusion all information of error rate in Table 3 and Figure 3:.

\section{Table 3}

Error analasys

\begin{tabular}{ccc}
\hline Histogram & Error rate & Haracteristics \\
\hline 1 & 3.2 & Plastic bottle on a uniform background \\
2 & 2.1 & Plastic bottle half on black background \\
3 & 2.4 & Glass jar cleaned \\
4 & 1.6 & Glass jar with contamination \\
\hline
\end{tabular}




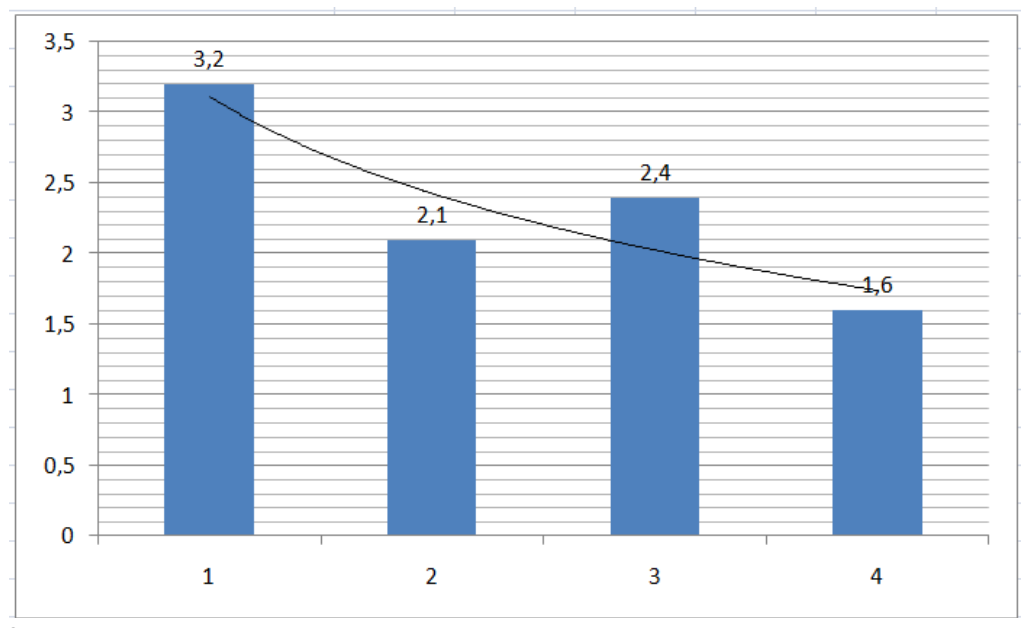

Figure 7: Result of error comparisons

As a result of the analysis (Figure 7:) of the received data, it is impossible to determine the exact dependence of the detection system on the contamination of the container or its illumination. The key role is still played by the complexity of the shape and the focus of the camera on the object. This confirms the fact that the bottle on the 4th histogram has the smallest error, but the maximum contamination.

In conclusion, it must be said that the target markets for the product are points of sale: hypermarkets, shopping centers, waste collection operators. Grocery and clothing stores, when installing the terminal, have a benefit, since the terminal gives out a discount on their products for the waste handed over, and it is at a specific address. Waste collection operators also benefit from the ability to quickly and accurately sort out well-traded waste automatically. The sales volumes of such automatic terminals are up to 40 pcs. in year. In the future, with the establishment of serial production, their volume can grow to 70 pieces per year. The development potential of these products will grow rapidly, since the trend of waste disposal due to the rise in prices will soon be no less relevant than electricity, gas, and water.

\section{Acknowledgements}

The authors thank the Council for Grants of the President of the Russian Federation for the grant SP-2381.2018.1, which allowed us to develop this topic and conduct large-scale research in the field of waste processing

\section{References}

[1] GOST R 54096-2010, Resource saving, Waste treatment, The relationship between the requirements of the Federal waste classification catalog and the all-Russian product classifier.

[2] V. T. Trofimov, Federal classification waste catalogue № 4107.6 (2005), appl. 02.12.2002, publ. 09.01.2003.

[3] K. Epifancev, D. Hvan, G. Morokina, I. Baranov, Development of software platform for collection and exchange of data in the field of waste management, IOP Conference Series: Materials Science and Engineering International Workshop "Advanced Technologies in Material Science, Mechanical and Automation Engineering - MIP: Engineering - 2019" (2019) 65-70.

[4] K. Epifancev, T. Mishura, Research of RDF-raw materials for prospective use in hardening construction and agricultural technologies, IOP Conference Series: Materials Science and Engineering (2019). DOI: 10.1088/1757-899X/537/6/062017.

[5] E. V. Katuntsov, J. Kultan, A. B. Makhovikov, Application of electronic learning tools for training of specialists in the field of information technologies for enterprises of mineral resources sector, Journal of Mining Institute 226 (2017) 503-8. 
[6] K. Epifancev, T. Mishura, O. Kozlova, A. Nikulin, Research of software verification methods for waste management and review the waste treatment legislation in Russia, E3S Web of Conferences 22001083 (2020).

[7] Retrieved from: https://zen.yandex.ru/media/okstanok/podborka-poleznyh-mobilnyh-prilojeniidlia-osoznannogo-potrebleniia-i-pererabotki-chast-1-5f27cf80289a6f736a892204.

[8] K. Epifancev, Using natural and technical systems of the Leningrad region for waste disposal, Journal of Physics: Conference Series 1515(5) 052059 (2020).

[9] Buyya, Object-oriented Programming with Java: Essentials and Applications, Tata McGraw-Hill Education (2009) 678. ISBN 9780070669086.

[10] L. G. Vartapetov, Ecological ornithology: textbook. manual for undergraduate and graduate programs, M.: Yurayt Publishing House, p. 170, 2019.

[11] T. F. Gurova, L. V. Nazarenko, Ecology and rational nature management: textbook and workshop for academic bachelor's degree, M.: Yurayt Publishing House, p. 188, 2019.

[12] N. N. Mitina, B. M. Malashenkov, Ecology: textbook and workshop for academic bachelor's degree, Ed. by V.I. Danilov-Danilyan, M.: Yurayt Publishing House, p. 363, 2019.

[13] O. Z. Eremchenko, Teaching about the biosphere: textbook. manual for academic bachelor's degree, M.: Yurayt Publishing House, p. 236, 2017.

[14] A. I. Zhirov, V. V. Dmitriev, A. N. Lastochkin, Textbook for academic undergraduate studies, Ed. by A I Zhirova, second ed., M.: Yurayt Publishing House, p. 311, 2019.

[15] V. Y. Bazhin, M. V. Glaz'ev, Combined Refractory Materials with Addition of Technogenic Waste for Metallurgical Assemblies, Refractories and Industrial Ceramics, 61(6) (2021) 644-648. 